\title{
BIRD OBSERVATIONS FROM THE MCLEOD RIVER AND ITS HEADWATER TRIBUTARIES, ALBERTA
}

KENNETH G. WRIGHT 6090 Blink Bonnie Road, West Vancouver, BC V7W 1V8

Here, I report on breeding birds observed while conducting field work on the upper McLeod River system ( $52^{\circ} 56^{\prime}$ $\mathrm{N}, 117^{\circ} 17^{\prime} \mathrm{W}$ ) and associated headwater tributaries during the period 18 - 23 June 1998. Bounded by Cardinal Divide to the south, the study area includes the McLeod River to its junction with Whitehorse Creek and the headwater tributaries: Harris Creek, Unamed "J" Creek (immediately northwest of Harris Creek), and Thornton and Cheviot Creeks. Sightings from a brief visit to an alpine plateau below Cheviot Mountain are also presented here. Situated a few kilometers east of Jasper National Park, this unique arctic-like setting is planned to be developed as a large-scale coal mine (Cardinal River Coals Ltd.).

Forty-three species were observed, of which thirty-two (74\%) were passerines. Three species (Cliff Swallow, Hirundo pyrrhonota, American Dipper, Cinclus mexicanus, Wilson's Warbler, Wilsonia pusilla) were confirmed breeding with the discovery of active nests (details below).

The species accounts that follow are in taxonomic order (American

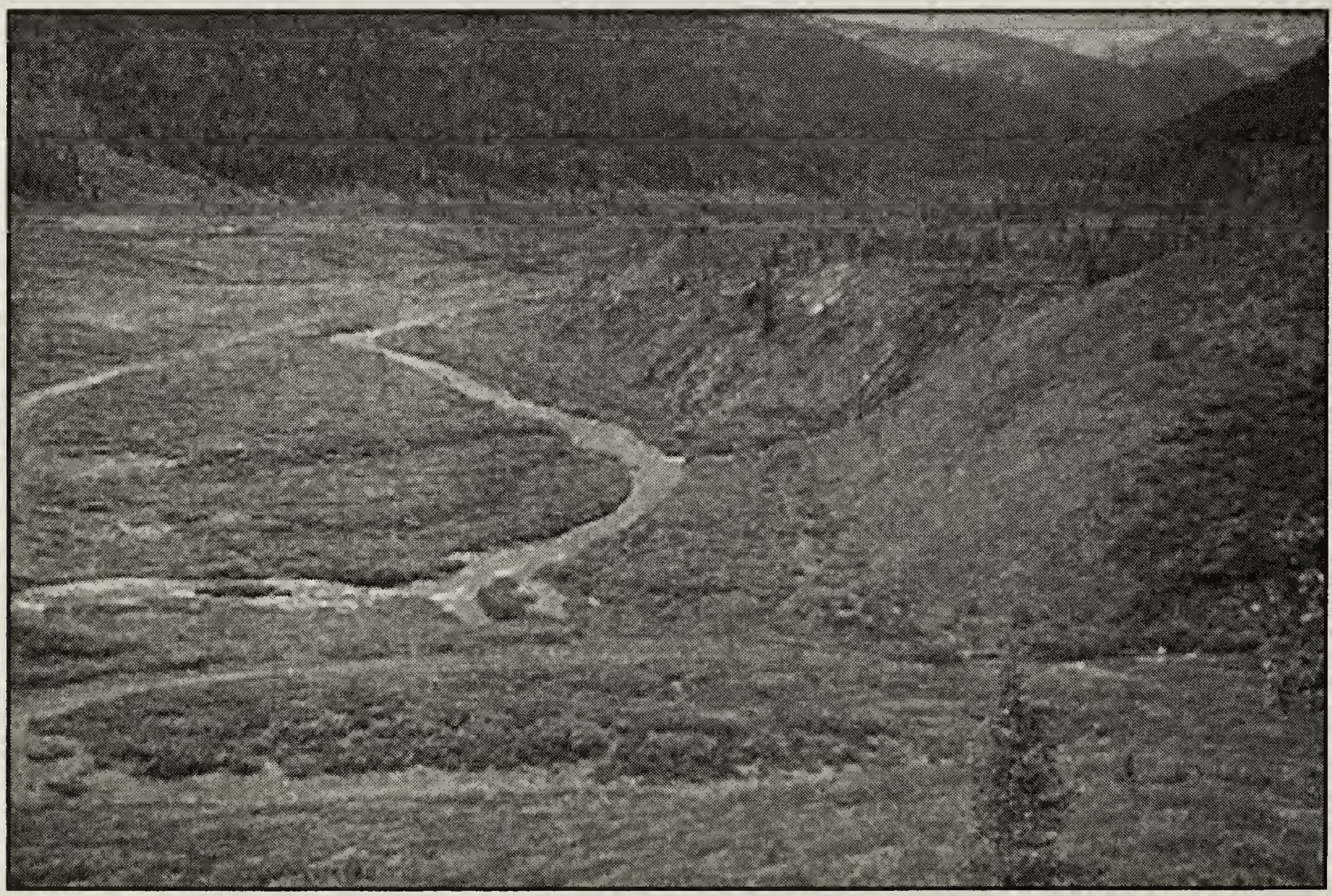

Figure 1 - Breeding Harlequin Duck habitat, Harris Creek and McLeod River confluence, Alberta, June 1998. Kenneth G. Wright 
Ornithologists' Union 1998). An asterisk $\left.{ }^{*}\right)$ precedes the common name of species confirmed breeding. Number of records for each bird species is listed as one, two or multiple observations $(>2)$. A short description of habitat and other relevant notes are included.

\section{Harlequin Duck (Histrionicus} histrionicus). Multiple obs. Females seen using Harris Creek, Unnamed "J" Creek, and the McLeod River adjacent to Prospect Creek, upstream of Prospect Creek and upstream of Thornton Creek, and especially the Harris Creek confluence area (Fig. 1)(Wright 1998). This species is known for its significant breeding population in the area (MacCallum 1997, MacCallum and Bugera 1998).

\section{Common Merganser (Mergus} merganser). Two records. Male seen at the Harris Creek / McLeod River confluence. A female on the McLeod River adjacent to Prospect Creek was also observed (23 June).

Northern Harrier (Circus cyaneus). Two records. An adult male was seen carrying a small mammal over lower Harris Creek (22 June) - possibly nest provisioning.

Northern Goshawk (Accipiter gentilis). One record. I heard a bird calling in dense spruce (Picea spp.) above a settling pond in Cheviot Creek. Possibly nesting.

Golden Eagle (Aquila chrysaetos). One record. Immature circling over Harris Creek, approximately $0.5 \mathrm{~km}$ upstream of McLeod River (23 June). Repeatedly mobbed by a male Northern Harrier.

Spotted Sandpiper (Actitis macularia). Multiple obs. Seen daily on specific stretches of the McLeod River and Harris and Thornton Creeks. Usually on creek banks and gravel bars, however some use of upland habitats in Harris Creek was noted.

Common Snipe (Gallinago gallinago). Multiple obs. Heard on several occasions winnowing near the McLeod River / Harris Creek confluence. Also flushed from wet meadows west of Thornton Creek. Maximum of 3 individuals observed at one site.

Great Horned Owl (Bubo virginianus). One record. Observed at dusk near Thornton Creek flying over the upper McLeod River (18 June).

Three-toed Woodpecker (Picoides tridactyla). Two records. Upper Cheviot Creek area in mature spruce forest.

Northern Flicker (Colaptes auratus). Multiple obs.

Pileated Woodpecker (Dryocopus pileatus). One record. Thornton Creek. Olive-sided Flycatcher (Contopus borealis). One record. Heard calling on the dry, west-facing slope of Mt. Harris, among old burned spruce snags (21 June).

Dusky Flycatcher (Empidonax oberholseri). Multiple obs. This species is confined mainly to the Rocky Mountain Foothill regions of Alberta (Semenchuk 1992).

Horned Lark (Eremophila alpestris). One record. Three individuals sighted on alpine plateau east of Cheviot Mountain (22 June).

Gray Jay (Perisoreus canadensis). Multiple obs.

Common Raven (Corvus corax). Multiple obs.

${ }^{*}$ Cliff Swallow (Hirundo pyrrhonota). Multiple obs. Locally common at vehicle bridge at McLeod River and Harris Creek where a nesting colony was present. Maximum count: $>50$ individuals.

Boreal Chickadee (Parus hudsonicus). One record. Cheviot Creek.

*American Dipper (Cinclus mexicanus). Multiple obs. Frequently observed near the confluence of Harris Creek and McLeod River. Nest located under crossing over McLeod River, 50 $m$ upstream of Harris Creek. Birds seen making provisioning trips up Harris Creek, unnamed "J" Creek and 
Thornton Creek. Favoured fast-flowing reaches with some exposed instream cobbles. Dippers are confined to the Rocky Mountain and Foothills regions (Semenchuk 1992).

Ruby-crowned Kinglet (Regulus calendula). Multiple obs. Cardinal Divide and Cheviot Creek.

Mountain Bluebird (Sialia currucoides). One record. A male observed at Cardinal Divide (20 June).

Gray-cheeked Thrush (Catharus minimus). Two records. One singing male 18 June in tall willow (Salix spp.) on south side of McLeod River approximately $1.5 \mathrm{~km}$ east of Prospect Creek. Another record of 2-3 birds singing in tall willow on the lower reach of Cheviot Creek (22 June). This species is mainly a migrant in Alberta (Salt and Salt 1976, Semenchuk 1992) however, they have been documented singing during the breeding season in the Rockies at Amethyst Lake, Jasper National Park (Van Tighem and Holroyd 1981) and Lake Louise, Banff National Park (McNicholl 1985). No definite breeding records exist for Alberta, however these observations and those reported from the Caribou Mountains of northern Alberta (Hohn and Burns 1975, Hohn and Marklevitz 1974) strongly suggest that localized breeding occurs.

Swainson's Thrush (Catharus ustulatus). One record. Cheviot Creek. Hermit Thrush (Catharus guttatus). One record. Cheviot Creek.

American Robin (Turdus migratorius). One record.

Varied Thrush (Ixoreus naevius). One record. One bird heard (22 June) in spruce draw above Cheviot Creek settling pond. Distribution is primarily in the Rocky Mountain and Foothills regions (Semenchuk 1992).

American Pipit (Anthus rubescens). One record. Three individuals on alpine plateau east of Cheviot Mountain (22 June).
Tennessee Warbler (Vermivora peregrina). Multiple obs. Fairly common in tall willow openings in spruce forest near Prospect Creek.

Yellow-rumped Warbler (Dendroica coronata). Multiple obs.

Northern Waterthrush (Seiurus noveboracensis). One record.

*Wilson's Warbler (Wilsonia pusilla). Multiple obs. Most common warbler. Particularly abundant in the dwarf birch/ willow habitat along streams (Fig. 2). A nest containing 5 eggs was found (21 June) on the ground below a small ( $<30$ $\mathrm{cm}$ high) Engelmann Spruce (Picea engelmanni). The nest was located approximately $100 \mathrm{~m}$ up Thornton Creek and was facing east. Female observed incubating at 1130 hours on 22 June. This species is an abundant breeder in the Rocky Mountain region (Semenchuk 1992).

Western Tanager (Piranga ludoviciana). One record. Cheviot Creek.

Chipping Sparrow (Spizella passerina). Multiple obs. Fairly common in spruce forest.

Clay-coloured Sparrow (Spizella pallida). Multiple obs.

Brewer's Sparrow (Spizella breweri taverneri). Multiple obs. This subspecies, formerly designated as a unique species (Timberline Sparrow) is confined to the Rocky Mountain Parks and adjacent mountain habitats (Semenchuk 1992). Little is presently known about its distribution in Alberta.

Savannah Sparrow (Passerculus sandwichensis). Multiple obs. At least two individuals observed at Harris Creek / McLeod River confluence.

Fox Sparrow (Passerella iliaca). Multiple obs.

Lincoln's Sparrow (Melospiza lincolnii). Multiple obs.

Golden-crowned Sparrow (Zonotrichia atricapilla). One record. Treeline on upper Cheviot Creek. Distributed primarily in the Rocky Mountain region 
(Semenchuk 1992).

White-crowned Sparrow (Zonotrichia leucophrys). Multiple obs. Very common in dwarf birch (Betula glandulosa) and willow meadows throughout the upper McLeod area. Likely the most common passerine in the study area.

Dark-eyed Junco (Junco hyemalis). Multiple obs. Fairly common in spruce forest and edge habitats.

White-winged Crossbill (Loxia leucoptera). One record. Male seen flying at treeline on upper Cheviot Creek. American Goldfinch (Carduelis tristis). One record. Harris Creek.

A rich avifauna (43 species) was observed in the upper McLeod River and associated tributaries during the period 18-23 June 1998. This area contains elements suitable for several species with a limited and patchy distribution. In particular, the area supports a significant Harlequin Duck breeding population, estimated at $58 \pm 7$ individuals
(MacCallum 1997). Harlequin Ducks are presently considered "Yellow listed" (species of management concern; Anonymous 1996) in Alberta and recent concerns over a possible declining population in British Columbia have stimulated several population studies. The Northern Goshawk observed giving a territorial call in Cheviot Creek may have been nesting in the spruce forest there. Northern Goshawks are not currently designated at risk in Alberta, however the subspecies A. g. laingi is considered threatened (Red list) in neighbouring British Columbia (Fraser and Cannings 1998). Little is known on the breeding distribution of the Graycheeked Thrush and Brewer's Sparrow in Alberta and the paucity of such records indicates a small population and patchy occurrence.

At present, a large-scale open pit coal mine development is imminently planned for the area, threatening many of the region's unique birds and habitats.

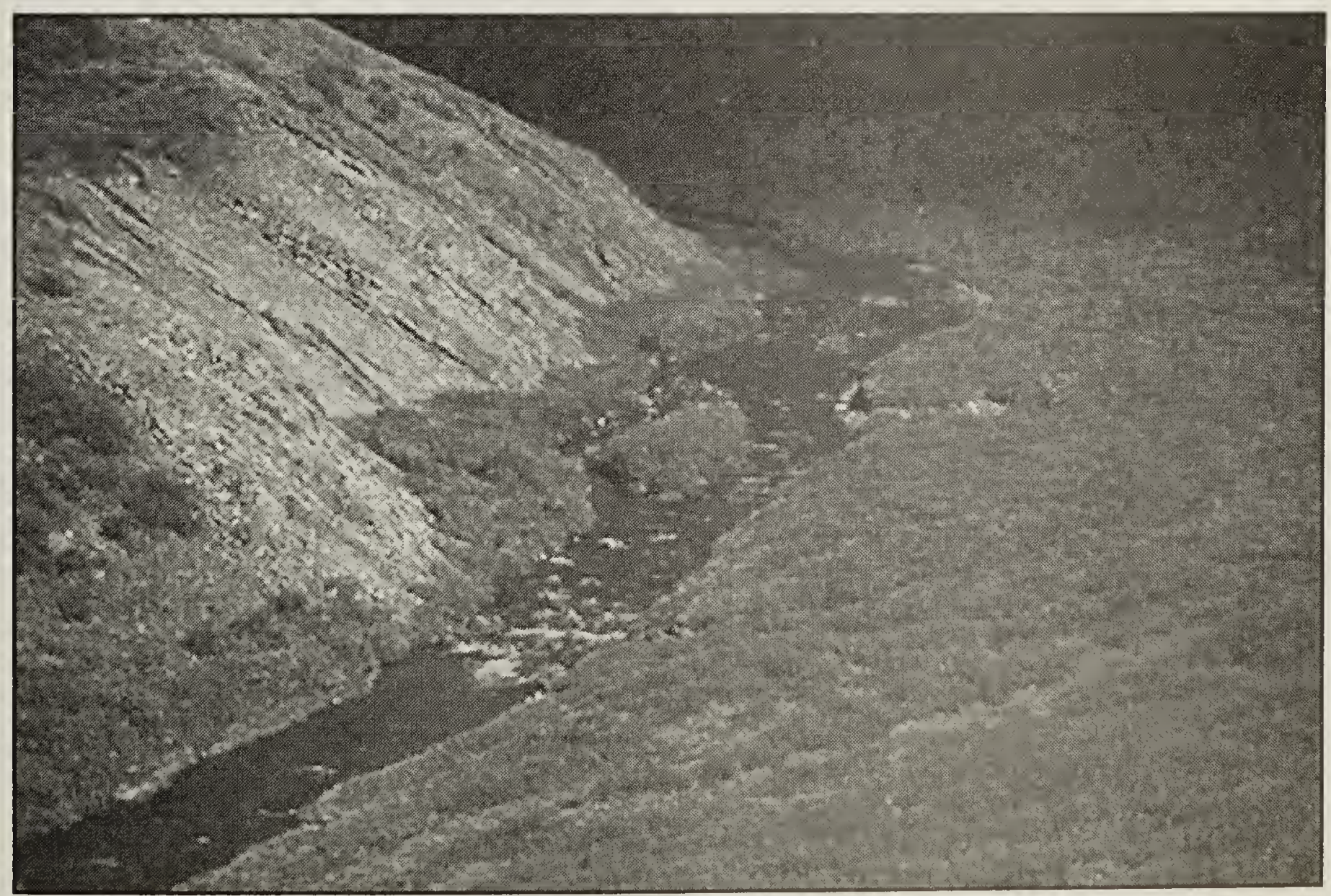

Figure 2 - Wilson's Warbler habitat, Harris Creek, Alberta, June 1998.

Kenneth G. Wright. 
Further work is urgently required to document the breeding status of the region's unique avifauna, in particular nesting confirmation for the Graycheeked Thrush and Brewer's Sparrow.

\section{Acknowledgements}

I thank Andy Miller for his observations and expertise while doing field work. Martin K. McNicholl and Michael I. Preston kindly provided useful references. Michael I. Preston critically reviewed the manuscipt. Funding for this work was provided by the Canadian Parks and Wilderness Society and the Canadian Nature Federation.

\section{Literature Cited}

\section{AMERICAN ORNITHOLOGISTS'} UNION. 1998. Check-list of North American Birds: Seventh Edition. Lawrence, Kansas. 829 pp.

2. ANONYMOUS. 1996. The status of Alberta wildlife. Alberta Environmental Protection, Natural Resources Service, Edmonton, Alberta.

3. FRASER, D.F., AND S.G. CANNINGS. 1998. 1998 Red and Blue lists for Amphibians, Reptiles, Birds, and Mammals. Wildlife Branch, Ministry of Environment, Lands and Parks, Victoria, B.C.

4. HÖHN, E.O., AND R.D. BURNS. 1975. A reconnaissance of the birds and mammals of the Caribou Mountains, Alberta. Blue Jay 33(2): 73-83.

\section{HÖHN, E.O., AND P. MARKLEVITZ.} 1974. Noteworthy summer observations of birds in the Caribou Mountains, Alberta. Can. Field Nat. 88(1): 77-78.
6. MacCALLUM, B. 1997. Abundance, distribution, and life history of Harlequin Ducks (Histrionicus histrionicus) in the McLeod River and adjacent streams of the Alberta Foothills. Prepared for Cardinal River Coals, Alberta Wildlife Management, Canadian Wildlife Service and Jasper National Park. Bighorn Environmental Design Ltd., Hinton, Alberta.

7. MacCALLUM, B., AND M. BUGERA. 1998. Harlequin Duck use of the McLeod River Watershed: 1997 Progress Report for the Cheviot Harlequin Duck Study. Prepared for Cardinal River Coals, Alberta Wildlife Management and Canadian Wildlife Service. Bighorn Environmental Design Ltd., Hinton, Alberta.

8. MCNICHOLL, M.K. 1985. Singing Gray-cheeked Thrush at Lake Louise, Alberta. Alberta Naturalist 15: 10-11.

9. SALT, W.R. AND J.R. SALT. 1976. The birds of Alberta. Queen's Printer, Edmonton. 498 pp.

10. SEMENCHUK, G.P. (editor). 1992. The atlas of breeding birds of Alberta. Federation of Alberta Naturalists, Edmonton. $391 \mathrm{pp}$.

11. VAN TIGHEM, K. AND G.L. HOLROYD. 1981. A Birder's Guide to Jasper National Park. Alberta Nat. 11:134-140.

12.WRIGHT, K. G. 1998. Observations of breeding Harlequin Ducks in the upper McLeod River, Alberta. Report to Canadian Parks and Wilderness Society. 